\title{
Cointegration Analysis of Agricultural Growth and Financial Inclusion in Ghana
}

\author{
Wonder Agbenyo*, Yuansheng Jiang, Siaw Antony \\ College of Economics, Sichuan Agricultural University, Chengdu, China \\ Email: *agbenyowonder@gmail.com
}

How to cite this paper: Agbenyo, W., Jiang, Y.S. and Antony, S. (2019) Cointegration Analysis of Agricultural Growth and Financial Inclusion in Ghana. Theoretical Economics Letters, 9, 895-911. https://doi.org/10.4236/tel.2019.94058

Received: December 24, 2018

Accepted: April 14, 2019

Published: April 17, 2019

Copyright $\odot 2019$ by author(s) and Scientific Research Publishing Inc. This work is licensed under the Creative Commons Attribution International License (CC BY 4.0).

http://creativecommons.org/licenses/by/4.0/ (c) (i) Open Access

\begin{abstract}
Agriculture remains the foundation of economic growth for any economy irrespective of their level of development. Being aware of the imperative role of finance in the endogenous growth model, it is admitted that access and usage of finance is critical for the growth of the agriculture sector. Access to and usage of financial services would enable the incorporation of rural farmers into the financial system. In the light of this revelation, this paper examined Cointegration Analysis of Agricultural Growth and Financial Inclusion in Ghana. Time series data from the period of 1980-2014, Johansen Cointegration approach coupled with Fully Modified Ordinary Least Square method (FMOLS) for the estimation of long-run relationship between agriculture growth and financial inclusion in Ghana using Eviews 9 was used. The study revealed that, domestic credit to private sector as proxied for usage has an inverse relationship but significant. The paper also revealed that lending interest rate proxy for accessibility of financial services to farmers portrayed significantly positive impact on the growth of agriculture. As provision of financial services alone cannot enable rural farmers attain financial inclusion, there is an urgent need for the provision of domestic credit to the private sector as they help promote economic growth implying that the better the private sector gets, the bigger role they played in the economy. Government should ensure that lending interest rate of both financial and non-financial institutions that support agriculture sector is flexible to enable farmers to easily have access to capital for expansion.
\end{abstract}

\section{Keywords}

Financial Inclusion, Agriculture Growth, Access, Usage, Johansen Cointegration, Ghana

\section{Introduction}

Agriculture remains the bedrock of economic growth for any economy irrespec- 
tive of their level of development. In fact, agriculture has widely been acknowledged as the foundation of every single economy and its role is undoubtedly huge and requires no civil argument. The role consolidates product contribution, market contribution, factor contribution and foreign exchange contribution Adeyinka et al., [1]. No doubt, agriculture is the most predominant sector and indeed a noteworthy source of livelihood for citizens (Ijaiya \& Abdulaheem, [2]). This is in light of the fact that apart from giving nourishment to the flooding masses of the economy, it is the main source of crude materials that different sectors watch out to before their production could manifest. According to Abayomi [3], expanding production in agriculture is seen as the most indispensable chaperon for accomplishing industrialization. As demonstrated by the latest census figures (Ghana Statistical Service, [4]) Ghana has a population of around 27.4 million and like most developing countries in Africa, agriculture is the breadwinner of the economy and around $70 \%$ of the population is rural.

Being aware of the imperative role of finance in the endogenous growth model, it is admitted that access to finance is critical for the growth of the agriculture sector hence the role of financial capital as an element of production to encourage financial development and additionally the need to properly channel credit to rural areas for economic improvement of the poor rural farmers cannot be overlooked. Policy organizations around the world such as (International Finance Corporation (IFC, [5]) and [6]; IFAD, [7], Kloeppinger-Todd and Sharma, [8]; Singh, [9]; Hill and Torero, [10]) affirmed that, financial inclusion serves as the key that can unlock the inclusive transformation of the rural environment. However, in developing countries such as Ghana, where agriculture is a source of livelihood for 86 percent of rural people (International Finance Corporation, [11]), financing for investments in agriculture is scarce, even for large investors. Figure 1 below presents a clear indication of the trend of the agriculture sector in Ghana.

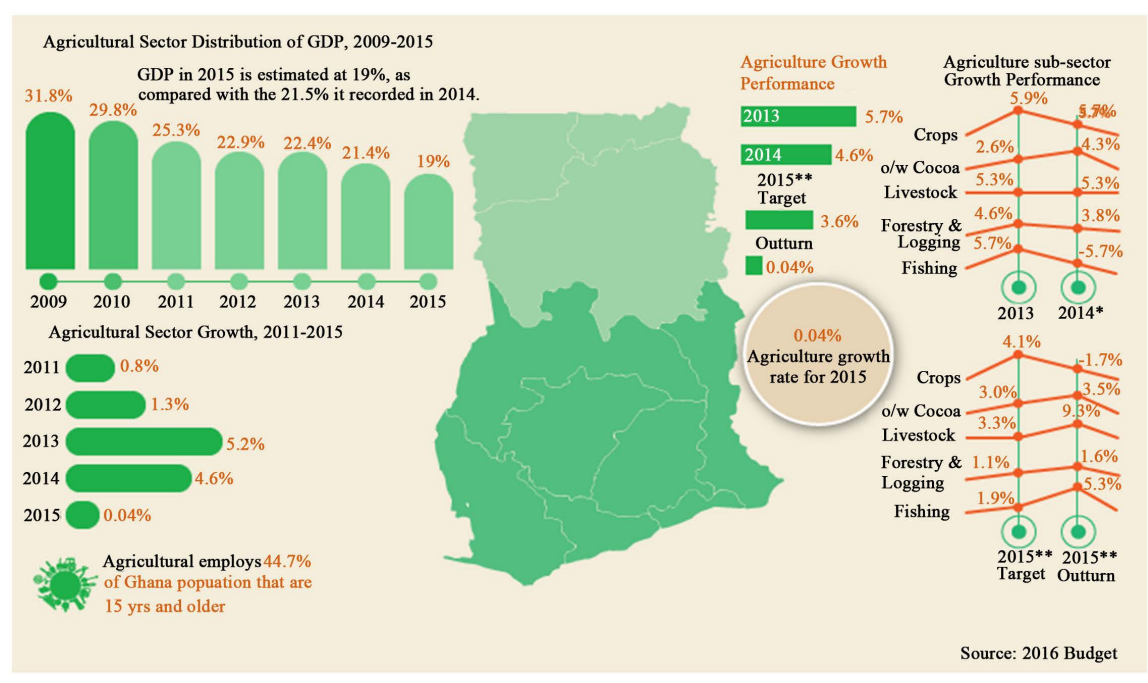

Figure 1. Trends in the growth of agriculture sector in Ghana. Source: Budget statement, 2016 (Adopted from Kwarase, 2017). 
With reference to the Figure 1, its evidence that there is continues reduction in the growth of the agriculture sector in Ghana. Kwarase, [12] disclosed that sectoral growth of the sector has not been consistent despite its imperative role to the economy. In the reports of Ghana Statistical Service [13] the achievement of 5.2 percent in 2013 as compared to 0.8 percent in 2011 portrayed a successful growth of the agriculture sector. However, this growth could not be maintained as there was a drastic reduction in the rate as compared to its previous years. For instance, in 2014 the sector recorded a lower growth rate of 4.6 percent as compared to the previous year 5.2 percent in 2013 and more severe in 2015 with a percentage of 2.5 as reported in the Ghana Statistical Service [13]. The question that remains an unanswered in literature and among policymakers is what are the contributing factors to this inconsistency growth rates of the agriculture sector in Ghana?

In most developing countries, agricultural producers particularly those in low-income countries, encounter different impediments including low productivity, constrained access to business sectors for their products, and above all these challenges is the accessibility to finance. While agriculture remains a key economic activity in Africa utilizing around 55\% of the populace, just about $1 \%$ of bank loaning goes to the agricultural sector. Moreover, only $4.7 \%$ of adults in rural areas in developing countries internationally have a credit from a formal financial institution and only 5.9\% with a bank account, according to Findex data. Most smallholder farmers do not have bank accounts and transactions are largely conducted by cash as indicated in a report of Global Findex data.

Knowing that lack of working capital and low liquidity limit the ability of farmers to purchase inputs that enhance productivity. According to Nyoro, [14] the situation has led to the use of inadequate improved farm inputs such as fertilizers, pesticides, and seeds among others. However, for growth in the agricultural sector, access to credit is crucial. Additionally, studies have found that people in rural areas, who are rarely studied, are also less likely to access financial institutions (Carbo et al., [15]). In spite of the several positive impacts of credit on agricultural production, empirical studies disclose that numerous factors limit access to it (Magri, [16]; Thaicharoen et al., [17]; Crook and Hochguertel, [18]; Del-Rio and Young, [19]; Singh, [20]). The Initiative for Smallholder Finance, [21] in its most current report, also estimated that credit from FIs gratifies only a segment of the agriculture-related financial needs of non-commercial smallholders and commercial smallholders in loose value chains. Majority of the literature on financial exclusion and inclusion focuses on the urban poor, and we know very little of the level of financial inclusion and exclusion in rural areas.

Efobi et al., [22] posit that, financial inclusion connotes increasing popular access to formal financial services such as a bank account, and/or the use of credit and saving facilities of banks. Kalunda, [23] also indicates that financial inclusion refers to the process of availing a range of required financial services, at a fair price, at the right place, in the right form and at the right time, through for- 
mal means and with no type of separation to the people. Access and usage of financial services is not just a want to be fulfilled but a need that must necessarily be met for agricultural growth. In a recent study of Olaniyi [24] on the impact of financial inclusion on agriculture in Nigeria, he disclosed that financial inclusion is an additional tool that can enable poor farmers to have more sustainable livelihoods. Other scholars also specified that financial inclusion leads to poverty reduction, decrease in the level of inequality and enhanced private investment (Allen et al., [25]; Beck, Demirguc-Kunt, \& Peria, [26]; Mbutor and Uba, [27]; Singh, [28]; Olaniyi, [24]; Abimbola et al., [29]). Other studies (including Mohan, [30]; Agarwal, [31]; Cnaan, Moodithaya and Handy, [32]; Shatrma and Kukreja, [33]; Paramasivan and Ganeshkumar, [34]) discovered that financial inclusion has a significant impact on economic growth.

It is indisputable that some commercial banks and microfinance institutions (MFIs) deploy specialized lending products for pre- and post-harvest finance, but these FIs are still exceptions in the financial market and rather limited to certain commodities. However, regardless of the diverse financial necessities in all the four categories of farmers, both informal and formal financial institutions (FIs) in Africa often fail to supply ample and suitable financial services, especially for agricultural production and agribusiness development of which Ghana is no exception to. Again AGRA [35], posits that two key critical components of an agricultural finance system are the supply of and demand for financial services. One unique difficulty of the system stems from the heterogeneity of actors on both sides. Emanating from the concerns iron out by various studies, this paper pursues to fill the huge gap left in literature especially to the lacking of studies on this particular area by seeking answers to the question if financial inclusion can influence the growth of agriculture in Ghana?

\section{Review of Related Literature}

Defining financial inclusion is viewed as pivotal from the perspective of building up a theoretical structure and recognizing the underlying variables that lead to low level of access to financial services (Gandhi, [36]). The agenda of financial inclusion has deeply influenced the decision of policymakers such as the World Bank, Consultative Group to Assist the Poor (CGAP, [37]), African Development Bank (ADB, [38]), and International Monetary Fund (IMF) to ensure the need for inclusiveness of the poor or the vulnerable in the financial sector. The first step towards determining the extent of financial inclusion is to identify the indicators that measure the level of accessibility, usage and quality of financial services in a country. Promoting efficient, sustainable and accessible rural financial system and financial services to rural farmers could make a potential impact on agriculture productivity, food security and poverty reduction. In terms of agricultural lending, the bank provides financial support to projects by holding equity and providing credit. The bank grants credit to various categories of customers including individuals, sole-proprietorship ventures, partnership enterprises, limited liability companies, large corporate organizations, registered 
co-operative societies, and organized groups involved in agricultural and related activities. Candidates are required to work/keep up a record with a Branch of the Bank.

Kyere [39], conducted a study on financial institutions and Agriculture financing in Ghana. The focus of the study was on how well Ghanaian commercial banks have performed in extending credit facilities to farmers in Ghana and the impact of the credit on this group of farmers and the economy as a whole. It was revealed that the higher rate of default among farmers is as a result of the tax collection procedures of the bank has seriously affected the liquidity and performance of the institution while the complicated procedures in loan applications approval and disbursement contributed to the inefficient utilization of the credit extended to the farmers. Olaniyi [24] revealed in his study that financial services have significant impacts on agriculture. Indicating that access to finance by farmers has significant impacts on agriculture growth.

\section{Recent Empirical Reviews}

Kareem, et al., [40], analyzed the components impacting Agricultural output in Nigeria. They focused on the macroeconomic points of view. The study seeks to determine the factors influencing agricultural production in Nigeria, and also determine the causality between Agricultural outputs and macroeconomic variables. The paper employed regression analysis, descriptive statistics and the Granger causality tests on macroeconomic factors to locate the critical connection between the diverse factors picked. The outcome indicates changes in the pattern of factors considered in connection to the period under survey. The result further shows that foreign direct investment: commercial bank loan, interest rate and food import value have a positive relationship with Agricultural output.

Money [41] investigated banks credit and agricultural development. The paper used primary and secondary sources of information that was extracted from five (5) banks and ten (10) agricultural enterprises in Delta State. Simple random sampling method through the lottery strategy was embrace to choose the samples. The data were analyzed using percentage, mean, and Standard Deviation and Pearson product moment correlation to test the hypotheses. The research findings include: that banks' credits and advances to agricultural entrepreneurs promote agricultural development and productivity, and that regulated banks' credits to the agricultural entrepreneurs have no or little effect on the business enterprise performance, and in this way, recommended satisfactory bank credits ought to be conceded to little scale agricultural entrepreneurs to build efficiency: and their farm ought to be utilized as insurance rather than the regular banks credit security to enhance business enterprise performance.

Udoka, Mbat and Duke, [42] also researched the effect of commercial banks credit on agricultural output in Nigeria. The study adopted the ex-post facto research design for the study. Data were collected from published articles and the central bank of Nigeria statistical bulletin. The study portrayed that there was a positive and significant relationship between commercial banks credit to the 
agricultural sector and agricultural production in Nigeria. The study recommended that the positive effect of agricultural credit guarantee scheme fund on agricultural production called for proper funding of the scheme by the government. Based on the findings of the study, it is recommended that the amount of credit available to small-scale farmers should be increased and disbursed promptly to ensure optimal utilization of the input. Also, for increased liquidity and for the bank to become self-sufficient, it should improve its loan recovery procedure and make desperate efforts to stem the high rate of default that has seriously affected the performance of the bank. The study observed that though the bank supported successive governments' agricultural policies, its contribution to the general agriculture performance in Ghana was not adequate.

Demirgüç-Kunt, Klapper, and Singer [43] study financial inclusion and legal discrimination among women from developing countries. The results from their probit models and ordinary least squares (OLS) regressions document that individual characteristics such as income, education, employment status, rural residence, age and gender remain significantly related to usage of financial services. The authors also find that legal discrimination against women and gender norms may explain some of the cross-country variation in access to finance by women. They observe that in countries where women face legal restrictions in their ability to work, head a household, choose where to live and receive an inheritance, women are less expected to own a bank account, in respect to men, as well as to spare and acquire. Their results also confirm that manifestations of gender norms, such as the level of violence against women and the incidence of early marriage for women, contribute to explaining the variety in the usage of financial services among people, in the wake of controlling for other individual and nation qualities.

In examining an overview of financial inclusion in Africa using descriptive statistics Demirgüç Kunt and Klapper [44], report that less than a quarter of adults in Africa have an account with formal financial institutions and that majority of adults in Africa make use of informal methods to save and borrow. Thus, 23\% of adult Africans have accounts at a formal financial institution and about $77 \%$ remained unbanked (do not have a bank account at a formal financial institution). Similarly, they observe that majority of small and medium enterprises in Africa are unbanked and access to finance is a major obstacle. As compared with other developing economies, the authors report that high-growth small and medium enterprises in Africa are less likely to use formal financing.

\section{Model Specification, Data and Estimation Techniques}

To ascertain whether financial Inclusion can influence the growth of the agriculture sector in Ghana, this paper employed and modify the model in the work of Onaolapo [45]. Time series data covering the period of 1980 to 2014 was used for the study. The sample period was based on the availability of data for all the variables used in the study. Annually collated time series data on Broad money, lending interest rate, agriculture share of GDP, government expenditure on 
agriculture, inflation and domestic credit to private sector were gathered from World Bank and Bank of Ghana annual Reports. From the above the model is specified as follows:

$$
A G=f(B M, L I R, G E A, D C P, e)
$$

where, $A G$ denotes the agriculture growth, $B M$ represent money supply, $L I R$ represents lending interest rate; $G E A$ as government expenditure on agriculture, $D C P$ denotes domestic credit to private sectors and $e$ as the stochastic error term that captures all relevant potential variables that were omitted from the model. The model is transformed into an econometric model as;

$$
A G=\beta_{0}+\beta_{1} B M+\beta_{2} L I R+\beta_{3} G E A+\beta_{4} D C P+\mu_{t}
$$

$\beta_{0}$ is the constant intercept and $\beta_{1}, \beta_{2}, \beta_{3}$ and $\beta_{4}$ are the parameter elasticity coefficients. Again, to enable the interpretation of the partial elasticities, which addresses the degree of responsiveness of the dependent variable to the respective economic independent variable, it is essential to introduce log into the model. This will transform the model into;

$$
\ln A G=\beta_{0}+\beta_{1} \ln B M+\beta_{2} \ln L I R+\beta_{3} \ln G E A+\beta_{4} \ln D C P+\mu_{t}
$$

\subsection{Theoretical and a Priori Assumptions}

Agriculture growth: agriculture is key to the management of natural resources, including land, forest, water and genetic biodiversity. This variable will be considered as the dependent variable. It will be used as the proxy for growth in agriculture in the Ghanaian economy. To examine the impact, share of agriculture to GDP is regressed on macroeconomic variables elaborated below.

Broad Money ( $B M)$ according to Findex Data on Ghana, is the sum of currency outside banks; demand deposits other than those of the central government; the time, savings, and foreign currency deposits of resident's sectors other than the central government; bank and travelers check and other securities. In simple terms, broad money refers to a country's money supply. World Bank [46] posits that financial deepening incorporates growth in the stock of financial assets. Nwagwugwu [47] in concordant defines financial deepening as the rise of the establishment of financial services with a broader choice of services geared towards the improvement of all levels of society. Building on this evidence, Onaolapo [45] explained financial deepening as the capability of financial organizations, in general, to efficiently mobilize financial resources for growth and development. In conclusion, Ibrahim, and Shuaibu, [48] portrayed that a high level of financial deepening is a necessary condition for fast-tracking growth in an economy. Hence, the expected sign of $\beta_{1}$ is positive.

Lending Interest Rate is the bank rate that usually meets the short- and medium-term financing needs of the private sector. This rate is normally differentiated according to the creditworthiness of borrowers and objectives of financing. Hence, it implies that the lower the lending interest rate in Ghana the more farmers can easily get access to funds to expand their production. The lending 
interest rate in this study serves as a proxy of accessibility of credit by farmers. It is therefore expected that the sign of this variable either be positive or negative. Thus, $\beta_{2}$ can be positive or negative.

Government Expenditure on Agriculture is the amount of money that the government spends on the agriculture sector for its development. From this simple definition, the variable is proxied as the availability of capital to the agriculture sector by the government and it is expected that the sign of this variable should be inverse. Thus, $\beta_{3}$ can be positive or negative.

Domestic credit to private sector; provision of credit facilities by private sectors to farmers in rural areas is an avenue of financial inclusion. This however is influenced by the soundness of the financial position of the private financial institutions. Admitting to this fact, the model incorporates domestic credit to private sector as a proxy of usage of credit to farmers. Hence, the expected sign of $\beta_{4}$ is positive or negative.

\subsection{Estimation Techniques}

\subsubsection{Pre-Test for Stationarity}

The used of time series data with econometric analysis demand for the testing of stationarity through the use of unit root test. Owing to this fact, the augmented Dickey-Fuller [49] is used to warrant the reliability of exploring the study by estimating the stationary properties of the variables stated above in order to avoid incorrect forecasting and misleading results. The pre-testing of the stationarity among the variables indicated that all the variables of interest were integrated of order one; this makes it appropriate to apply the Johansen cointegration test to compute the empirical model.

\subsubsection{Cointegration Test}

After performing the stationarity test on the series, it is important to examine if there is an existence of a long-run relationship among the variables. Engle-Granger [50], and Phillips and Quliaris [51] are traditional approaches for evaluating cointegrating relationships reasonable for single equation models. When applying time series data to a study it is essential to perform cointegration test even though the variables employed might not be stationary in levels however the regression relationship of this variables do have a long-run relationship. Enders, [52] and Wooldridge, [53] argues that the t-distribution of the Ordinary Least Square (OLS) is asymptotic even though the ordinary least squares (OLS) estimators are consistent. To achieve asymptotic effectiveness, the Fully Modified Ordinary Least Squares (FMOLS) method alters Ordinary Least Squares to represent sequential connection impacts and test for endogeneity coming about because of cointegrating connections (Kalim \& Shahbaz, [54]) was employed. For this, it applies a semi-parametric remedy method. The FMOLS model is specified below; The FMOLS model is specified below;

$$
A G=\vartheta_{t}^{\prime} \alpha+\lambda_{1 t}^{\prime} \omega_{t}+\varepsilon_{1 t}
$$

where $\omega_{t}=\left[\lambda_{1 t}^{\prime}, \lambda_{2 t}^{\prime}\right]^{\prime}$ denotes deterministic trend regressor and 
$\vartheta_{t}^{\prime}=[B M, G E A, L I R, D C P]$ denotes the stochastic regressors derived in the equation portrayed below where $\vartheta$ is 4 .

$$
\begin{gathered}
\vartheta_{t}=\lambda_{1 t}+\lambda_{2 t}+\mu_{2 t} \\
\Delta \mu_{\delta t}=\varepsilon_{2 t}
\end{gathered}
$$

In the paper, $\lambda_{1 t}$ contains only the constant whereas $\lambda_{2 t}$ denotes the deterministic trend. Hence, the Fully Modified Ordinary Least Square (FMOLS) estimator is as follow:

$$
\hat{\eta}_{F M O L S}=\left(\begin{array}{c}
\hat{\alpha} \\
\hat{\omega}_{1}
\end{array}\right)=\left[\sum_{t=1}^{N} M_{t} M_{t}^{\prime}\right]^{-{ }^{\prime}}\left[\sum_{t=1}^{N} M_{t} A G_{t}^{\prime}-N\left[\begin{array}{c}
\hat{\delta}_{12}^{+} \\
0
\end{array}\right]\right]
$$

where $M_{t}=\left[\vartheta_{t}^{\prime}, \lambda_{1}^{\prime}\right]$ dir. Using $\hat{\varrho}$ and $\hat{\rho}$ to be long-run covariance matrices obtained by using the residuals $\hat{\vartheta}_{t}=\left[\hat{\vartheta}_{1 t}, \hat{\vartheta}_{2 t}^{\prime}\right]^{\prime}$ the modified data can be explained as;

$$
A G_{t}^{+}=A G_{t}-\hat{\gamma}_{12} \hat{Q}_{22}^{-1} \hat{\rho}_{2}
$$

The bias correction term estimation also takes the form;

$$
\hat{\delta}_{12}^{+}=\hat{\delta}_{12}-\hat{\gamma}_{12} \hat{\varrho}_{22}^{-1} \hat{\delta}_{22}
$$

\section{Empirical Results and Analysis}

\subsection{Test for Stationarity}

The state of stationarity among all variables was performed using the Augmented Dicker-Fuller test as outlined in the methodology of the study. The result of the unit root test is presented in Table 1 below.

Table 1. Results for augmented dickey-fuller Stationarity test.

(a)

\begin{tabular}{cccc}
\hline \multirow{2}{*}{ Variables } & \multicolumn{2}{c}{ Augmented Dickey-Fuller } & \multirow{2}{*}{ IO } \\
\cline { 2 - 3 } & No Trend & Trend & - \\
\cline { 2 - 3 } & -0.151470 & -2.529907 & - \\
LNAG & -0.848819 & -3.039243 & - \\
LNBM & -2.010094 & -1.857834 & - \\
LNLIR & -1.934129 & -1.861184 & - \\
LNGEA & -0.861408 & -2.690403 & - \\
LNDCP & &
\end{tabular}

(b)

\begin{tabular}{cccc}
\hline \multirow{2}{*}{ Variables } & \multicolumn{2}{c}{ Augmented Dickey-Fuller } & \multirow{2}{*}{ IO } \\
\cline { 2 - 3 } & \multicolumn{2}{c}{ First Difference } & \\
\cline { 2 - 3 } & $-6.775719^{* * *}$ & $-6.797043^{* * *}$ & I $(1)$ \\
LNAG & $-6.469992^{* * *}$ & $-6.390611^{* * *}$ & I $(1)$ \\
LNBM & $-6.123371^{* * *}$ & $-6.136867^{* * *}$ & I (1) \\
LNLIR & $-4.736726^{* * *}$ & $-4.695988^{* * *}$ & I $(1)$ \\
LNGEA & $-6.499886^{* * *}$ & $-6.451477^{* * *}$ & I (1) \\
LNDCP & & & \\
\hline
\end{tabular}

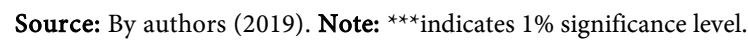


Evidence from the results in Table 1 depicts that all the series were found to be stationary at first difference, therefore being integrated of order one [i.e. I (1)]. There are basically three results after conducting a stationary test. The first outcome is when the series are integrated of order zero which requires no differencing. The second likely outcome is that all the series are integrated of order one which implies that the variables are stationary after first difference and the final likely outcome after testing stationarity is that the series are integrated of different orders. In this paper, the study confirmed the stationarity of all dictates variables at their first difference, hence being integrated first order [i.e. I (1)]. With this result performing cointegration test is necessary to establish a long run relationship. Hence, the study assumes that a long run relationship in the model regardless of the fact that the series are wandering apart or trending either upward or downward. Literature holds that when stationarity results of series are I (1), there are two test that .can be performed to establish the cointegration. Thus, the study considered it appropriate to apply the Johansen cointegration test to compute the empirical model due to the stationarity of the series results [i.e. I (1)].

\subsection{Johansen Test for Cointegration}

The Johansen test was employed to assess the existence of a cointegrating relationship between the underlying variables. The results of the Johansen tests are displayed in Table 2 below.

Table 2. Johansen test for cointegration results.

\begin{tabular}{|c|c|c|c|c|}
\hline \multicolumn{5}{|c|}{ Trace Statics } \\
\hline $\begin{array}{c}\text { Null } \\
\text { Hypothesis }\end{array}$ & $\begin{array}{l}\text { Alternative } \\
\text { Hypothesis }\end{array}$ & $\begin{array}{c}\text { Test } \\
\text { Statistics }\end{array}$ & $\begin{array}{l}5 \% \text { Critical } \\
\text { Value }\end{array}$ & Prob. Value \\
\hline$H_{0}: r \leq 0$ & $H_{0}: r>0$ & 130.1676 & 95.75366 & 0.0000 \\
\hline$H_{0}: r \leq 1$ & $H_{0}: r>1$ & $75.58240^{* * *}$ & 69.81889 & 0.0161 \\
\hline$H_{0}: r \leq 2$ & $H_{0}: r>2$ & 40.34318 & 47.85613 & 0.2105 \\
\hline$H_{0}: r \leq 3$ & $H_{0}: r>3$ & 14.74594 & 29.79707 & 0.7963 \\
\hline$H_{0}: r \leq 4$ & $H_{0}: r>4$ & 5.300786 & 15.49471 & 0.7761 \\
\hline$H_{0}: r \leq 5$ & $H_{0}: r>5$ & 0.046741 & 3.841466 & 0.8288 \\
\hline \multicolumn{5}{|c|}{ Maximum Eigenvalue Statistic } \\
\hline Null & Alternative & Test & $5 \%$ Critical & Prob. \\
\hline Hypothesis & Hypothesis & Statistics & Value & Value \\
\hline$H_{0}: r \leq 0$ & $H_{0}: r>0$ & $54.58519^{* * *}$ & 40.07757 & 0.0006 \\
\hline$H_{0}: r \leq 1$ & $H_{0}: r>1$ & $35.23922^{\star * *}$ & 33.87687 & 0.0342 \\
\hline$H_{0}: r \leq 2$ & $H_{0}: r>2$ & 25.59724 & 27.58434 & 0.0879 \\
\hline$H_{0}: r \leq 3$ & $H_{0}: r>3$ & 9.445158 & 21.13162 & 0.7950 \\
\hline$H_{0}: r \leq 4$ & $H_{0}: r>4$ & 5.254045 & 14.26460 & 0.7095 \\
\hline
\end{tabular}

Source: Eviews 9 software generated results. ${ }^{*}$ Note ${ }^{* * *}$ means rejection of the hypothesis at $1 \%$ significance level. 
From the results displayed in Table 2, the existence of long-run equilibrium relationship between agriculture growth and its exogeneous variables can be established in two ways when using the Johansen test for cointegration. The decision criteria posit that the null hypothesis which states that there no cointegration equation should be rejected at $5 \%$ of if the value of Trace and Max statistic $>5 \%$ critical value (Johansen, \& Juselius, [55]). Evidence based on the result from Table clearly indicates that the null hypothesis of no cointegration is rejected since the value of Trace (130.1676) and Max (54.58519) values are greater than the both critical $5 \%$ value level. This hence affirmed that there is a cointegrating relationship between the agriculture growth and independent variables used in this study.

\subsection{Long-Run Estimation Results}

Table 3 below depicts the long-run correlation between agriculture growth and its exogenous variables.

With respect to the long-run estimation through the FMOLS displayed in $\mathrm{Ta}$ ble 3 below, the study found government expenditure proxied as availability which is a measurement dimension of financial inclusion to have a significant positive impact on agriculture growth. This implies that a percentage increase in government expenditure will lead to a similar percentage increase in the growth of agriculture in the Ghanaian economy. In other words, $1 \%$ increase in government expenditure will make available capital for farmers to expand their production and thereby drawing farmers closer to the financial system since expansion in production can lead to a better living standard of the rural farmers. However, in the previous year availability (government expenditure on agriculture) was found to have a significant negative impact on the growth of agriculture. By implication when there's lack of capital (i.e. non-availability of funds

Table 3. Estimated fully modified ordinary least squares (FMOLS) results.

\begin{tabular}{ccccc}
\hline \multicolumn{4}{c}{ Dependable variable: LAG } & \\
\hline Regressors & Coefficient & Std. Error & t-Statistic & P-Value \\
\hline LAG (-1) & 0.665139 & 0.110973 & 5.993716 & 0.0000 \\
LGEA & 0.044604 & 0.019030 & 2.343923 & 0.0270 \\
LGEA (-1) & -0.050897 & 0.019963 & -2.549506 & 0.0170 \\
LDCP & -0.176114 & 0.052332 & -3.365302 & 0.0024 \\
LBM & 0.044119 & 0.092129 & 0.478878 & 0.6360 \\
LLENDING_RATE & 0.112459 & 0.062814 & 1.790360 & 0.0850 \\
Constant & 1.035521 & 0.535883 & 1.932362 & 0.0643 \\
R-squared & 0.892277 & Mean dependent var & 3.593656 \\
Adjusted R-squared & 0.867418 & S.D. dependent var & 0.277552 \\
S.E. of regression & 0.101062 & Sum squared resid & 0.265550 \\
Long-run variance & 0.004118 & & \\
\hline
\end{tabular}

Source: Eviews 9 software generated results. Note: ${ }^{*},{ }^{* *}$ and ${ }^{* * *}$ indicates significance at $10 \%, 5 \%$ and $1 \%$ level respectively. 
from the government) in relation to support the agriculture sector there will be a negative impact on the growth of agriculture (LGEA $\left.(-1) \sim \beta_{3}-0.050897\right)$. The finding was found to be in line with the studies of Chandio et al., [56], and Tijani et al., [57] and also satisfy the theory of Musgrave on public expenditure growth. The theory argues that what is necessary most for government expenditure is how efficient it is. When government of Ghana allocate public funds to their respective sectors efficiently there will be positive impact on the sectors especially that of the agriculture sector. This finding also satisfies the figure above in the background of the study as government expenditure to the sector is low the growth of the sector is equally reducing drastically.

The study again used domestic credit to private sector as a proxy for usage in this paper for financial inclusion dimension indicator according to the G20 financial inclusion indicators. The domestic credit to private sector was found to have a negative and significant impact on agriculture growth in the long-run. This implies that with a $1 \%$ decrease in domestic credit to private sector will reduce the usage of funds by the private sector by $0.176114 \%$ to the agriculture sector hence portraying a slow growth in the sector. This finding contradicts the study of Olaniyi [24] who used outstanding loans from the financial sector to the agriculture sector as percentage of GDP in Nigeria for the proxy of usage in his study. This could be true since there are different regulations governing the operations of every economy. However, the finding is in line with Izhar and Tariq [58] who revealed that, there was no significant influence on the agricultural sector of India in the period of their post-reform.

The study further discovered that, the expansion in money supply positively influence the growth of agriculture in Ghana in the long run but not statistically significant at any conventional level of significance. Statistically, a coefficient of 0.044 suggests that $1 \%$ increase in the supply of money would cause the growth of agriculture to increase by $0.04 \%$. This finding is not shocking as the previous year value of government expenditure on agriculture portrayed a negative impact and domestic credit to private sector also indicate a negative impact revealing that the supply of money could truly increase the liquidity of farmers making them part of the informal financial system which could satisfy part of the definition of financial inclusion but the means or channels through which this will work are inconsistent and lacking the supply of money. This finding again contradicts the findings of Dorfman and Lastrapes [59], and Olaniyi [24], who discovered in his study that money supply has significant positive effect on the growth of agriculture in Nigeria.

Lending interest rate has significantly positive effect on the growth of agriculture. Lending interest rate was proxied for accessibility of financial services to measure financial inclusion of farmers. This is in the notion that with low lending interest rates would manipulate the cost of borrowing, savings, purchasing of farm inputs and will also enable farmers to access capital for the expansion of their agriculture production thereby influencing the growth of agriculture. The vice versa is expected when lending interest rate is high. This revelation affirmed 
that of Das et al., [60] which disclosed that one critical factor to influence the growth in agriculture production is the accessibility to credit. In the study of Acha [61] conducted in Nigeria, he revealed that non-bank financial institutions' credit has significant influence on the agricultural share of GDP in Nigeria. Finally, Onyishi, Arene and Ifiorah [62] also established that average lending interest rate is positive and statistically significant at $5 \%$ during the period of deregulation in Nigeria. The finding however contradicts that of Olaniyi [24] study who asserted that lending interest rates are not significant and has a negative impact on agriculture but admitted to the fact that interest rates could have significant impact on the growth of agriculture by influencing the cost of borrowing, investment and savings.

\section{Conclusions and Policy Recommendation}

This paper using time series data covering the period of 1980-2014 and the Johansen cointegration approach coupled with Fully Modified Ordinary Least Square (FMOLS) to examine the long-run relation between the growth of agriculture and financial inclusion in the Ghanaian economy. The results revealed that government expenditure proxy for availability of capital to the agriculture sector or to the rural farmers has significant effect on the growth of agriculture. It was also discovered that domestic credit to private sector in Ghana proxy for usage has an inverse relationship but significant. On the divergent, broad money proxy for money supply in this study has a positive impact on the growth of agriculture but was however not statistically significant at any level of conventional significance. The study finally discovered that lending interest rate proxy for accessibility of financial services to farmers portrayed significantly positive impact on the growth of agriculture in Ghana. Evidentially from the findings of the study, it is unquestionable that financial inclusion is an imperative driver of the growth of agriculture. In order for the Ghanaian economy to attain economic development in rural areas and enhance agriculture growth incorporating farmers into the financial system is crucial. According to Sarma and Pais [63], financial system (or process) is said to be inclusive when it ensures availability, ease of access and usage of existing financial superstructure by all manner of people within society, regardless of their socio-economic status. This way the Ghanaian financial system can be able to efficiently allocate financial resources to the agriculture sector. Access to finance to farmers in this study shows a significantly positive impact on agriculture however according to Efobi et al., [22] financial exclusion refers to obstacles that hamper access to formal financial services (such as the distance to financial institutions, costs of financial services, lack of widespread knowledge of available services, integrity of regulatory and institutional infrastructure etc.), despite the surpassing marginal advantages over marginal cost from using these services.

In Ghana, according to the Bank of Ghana, one major aim for the establishment of rural banks in the rural communities is to provide easy access and credit facilities to the people of the rural communities and help them to tap the enor- 
mous natural resources of the area through the realise of this credit to farmers and deserved applicants but in recent times these rural banks are difficult to be accessed in the rural areas of the country since majority of them have relocated to the urban areas of the country in search of customers. As this paper has established, access to finance to rural farmers has positive impact and significant hence must be considered critically if the Ghanaian rural farmers and the growth of agriculture sector must see the day light of inclusive finance to enhance economic growth. The existing credit unions, savings and loans companies, donors and government must be ready to tap the huge lying opportunity in the rural sector of the country.

Again, in order to establish financial inclusion and improve the growth of agriculture in Ghana, the government and policy makers must develop policies that can capture farmers under one umbrella. With farmers under one umbrella the government can easily identify the exact demand of these farmers and can at the same time have accurate data as to how to allocate agriculture expenditure to especially the small-scale farmers who are always excluded from the policies currently available. Government should make it a necessity of making lending rate of banks that support agriculture sector lower to enable farmers to easily have access to capital.

\section{Conflicts of Interest}

The authors declare no conflicts of interest regarding the publication of this paper.

\section{References}

[1] Adeyinka, A.J., Daniel, A.A. and Olukotun, G.A. (2015) An Assessment of the Contributions of Commercial Banks to Agricultural Financing in The Nigerian Economy. International Journal of Advanced Academic Research Social Sciences and Education, 1, 1-16.

[2] Ijaiya, G.T. and Abdulraheem, A. (2000) Commercial Banks Credits to the Agricultural Sector and Poverty Reduction in Nigeria. Nigeria Journal of Agricbiz and Rural Development, 40, 12.

[3] Abayomi, F. (2006) An Overview of Nigerian Agricultural Sectors. Journal of Agricultural Economics, 8, 7-16.

[4] Ghana Statistical Service (2015) Economy of Ghana.

[5] International Finance Corporation (IFC) Capital Markets Department (2011) Emerging Stock Markets, Factbook. World Bank.

[6] International Finance Corporation (IFC) Capital Markets Department (2012) Emerging Stock Markets, Factbook. World Bank.

[7] International Fund for Agricultural Development (2009) Gender in Agriculture Sourcebook. World Bank Publications.

[8] Kloeppinger, T.R. and Sharma, M. (2010) Innovations in Rural and Agriculture Finance. Agriculture, and the Environment Focus.

[9] Singh, A.P. (2017) Does FDI Promote Productivity? A Deep Dive. Indian Journal of Industrial Relations, 52, 443-455. 
http://www.jstor.org/action/showPublication?journalCode=indijindurela

[10] Hill, R.V. and Torero, M. (2010) Innovations in Insuring the Poor. International Food Policy Research Institute.

[11] IFC (2013). http://documents.worldbank.org/curated/en/728101468326955026/Main-report

[12] Kwarase, P.K. (2017) Analysing Trends in Agricultural Output in Ghana 1995-2015: Underlying Causes and Options for Sustainable Growth. Doctoral Dissertation.

[13] Ghana Statistical Service. (2016) Revised 2015 Annual Gross Domestic Product. Ghana Statistical Service, Ghana, Accra.

[14] Nyoro, J.K. (2002) Agriculture and Rural Growth in Kenya. Tegemeo Institute, Egerton University.

[15] Carbo, S., Gardener, E.P. and Molyneux, P. (2005) Financial Exclusion in Europe. In Financial Exclusion, Palgrave Macmillan, UK, 98-111.

[16] Magri, S. (2002) Italian Households' Debt: Determinants of Demand and Supply. No. 454, Bank of Italy, Economic Research and International Relations Area.

[17] Thaicharoen, Y., Ariyapruchya, K. and Chucherd, T. (2004) Rising Thai Household Debt: Assessing Risks and Policy Implications. Monetary Policy Group, Bank of Thailand. http://www.bot.or.th/Thai/EconomicConditions/Semin ... Load/paper1_2547.pdf

[18] Crook, J. and Hochguertel, S. (2005) Household Debt and Credit Constraints: Evidence from OECD Countries. University of Edinburgh, Credit Research Center.

[19] Del-Rio, A. and Young, G. (2005) The Determinants of Unsecured Borrowing: Evidence from the British Household Panel Survey. Bank of England Working Paper, No. 263.

[20] Singh, A.P. (2018) Does Size Matter? - The Effect of Size of Production Workers, Management Staff and Proprietors on Productivity. Theoretical Economics Letters, 8, 2290-2307. https://doi.org/10.4236/tel.2018.811149

[21] ISF (2016).

https://thegiin.org/research/publication/inflection-point-unlocking-growth-in-the-e ra-of-farmer-finance

[22] Efobi, U., Beecroft, I. and Osabuohien, E. (2014) Access to and Use of Bank Services in Nigeria: Micro-Econometric Evidence. Review of Development Finance, 4, 104-114. https://doi.org/10.1016/j.rdf.2014.05.002

[23] Kalunda, E. (2014) Financial Inclusion Impact on Small-Scale Tea Farmers in Nyeri County, Kenya. World Journal of Social Sciences, 4, 130-139.

[24] Olaniyi, E. (2017) Back to the Land: The Impact of Financial Inclusion on Agriculture in Nigeria. Iranian Economic Review, 21, 885-903.

[25] Allen, F., Carletti, E., Cull, R., Qian, J.Q., Senbet, L. and Valenzuela, P. (2014) The African Financial Development and Financial Inclusion Gaps. Journal of African Economies, 23, 614-642. https://doi.org/10.1093/jae/eju015

[26] Beck, T., Demirguc-Kunt, A. and Martinez, M.S.P. (2006) Banking Services for Everyone? Barriers to Bank Access and Use around the World. The World Bank, Washington DC.

[27] Mbutor, M.O. and Uba, I.A. (2013) The Impact of Financial Inclusion on Monetary Policy in Nigeria. Journal of Economics and International Finance, 5, 318-326. https://doi.org/10.5897/JEIF2013.0541

[28] Singh, A.P. (2016) R and D Spillovers and Productivity Growth: Evidence from In- 
dian Manufacturing. Indian Journal of Industrial Relations, 51, 563-579.

[29] Abimbola, A., Olokoyo, F.O., Babalola, O. and Farouk, E. (2018) Financial Inclusion as a Catalyst for Poverty Reduction in Nigeria. International Journal of Scientific Research and Management, 6, 481-490.

[30] Mohan, R. (2006) Economic Growth, Financial Deepening, and Financial Inclusion. Hyderabad, 3 November 2006.

[31] Agarwal, A. (2010) Financial Deepening, Financial Inclusion: Challenges and Opportunities. The 23rd Skoch Summit.

[32] Cnaan, R.A., Moodithaya, M.S. and Handy, F. (2012) Financial Inclusion: Lessons from Rural South India. Journal of Social Policy, 41, 183-205. https://doi.org/10.1017/S0047279411000377

[33] Shatrma, A. and Kukreja, S. (2013) An Analytical Study: Relevance of Financial Inclusion for Developing Nations. International Journal of Engineering and Science, 2, 15-20.

[34] Paramasivan, C. and Ganeshkumar, V. (2013) Overview of Financial Inclusion in India. International Journal of Management and Development Studies, 2, 45-49.

[35] AGRA (2017) Strengthening Financial Systems for Smallholder. https://agra.org/aasr2017/chapter-4/

[36] Gandhi, M.M. (2013) Financial Inclusion in India: Issues and Challenges. International Multidisciplinary Journal of Applied Research, 1, 12-22.

[37] Consultative Group to Assist the Poor (CGAP) (2009) Financial Access 2009: Measuring Access to Financial Services around the World. Washington DC.

[38] African Development Bank (2013) Financial Inclusion in Africa. African Development Bank Group, Ghana.

[39] Kyere, I. (2014) Financial Institutions and Agricultural Financing in Ghana: The Case of the Ghana Commercial Bank 1953-1994. Doctoral Dissertation, University of Ghana, Ghana.

[40] Kareem, R., Bakare, H., Raheem, K., Ologunla, S., Alawode, O. and Ademoyewa, G. (2013) Analysis of Factors Influencing Agricultural Output in Nigeria: Macro-Economic Perspectives. American Journal of Business, Economics and Management, 1, 9-15.

[41] Money, U. (2014) Bank Credits and Agricultural Development: Does It Promote Entrepreneurship Performance. International Journal of Business and Social Science, 5, 102-107.

[42] Udoka, C.O., Mbat, D.O. and Duke, S.B. (2016) The Effect of Commercial Banks' Credit on Agricultural Production in Nigeria. Journal of Finance and Accounting, 4, 1-10.

[43] Demirguc-Kunt, A., Klapper, L. and Singer, D. (2017) Financial Inclusion and Inclusive Growth: A Review of Recent Empirical Evidence. The World Bank, Washington DC.

[44] Demirgüç-Kunt, A. and Klapper, L.F. (2012) Measuring Financial Inclusion: The Global Findex Database.

[45] Onaolapo, A.R. (2015) Effects of Financial Inclusion on the Economic Growth of Nigeria (1982-2012). International Journal of Business and Management Review, 3, 11-28.

[46] World Bank (2009) World Development Indicatorson Online (WDI) Database. World Bank, Washington DC. http://www.worldbank.org 
[47] Nwaogwugwo, I.C. (2008) Stock Market Development and Economic Growth in Nigeria: The Causal Linkage. Nigerian Journal of Securities and Finance, 13, 115-124.

[48] Ibrahim, T.M. and Shuaibu, M.I. (2013) Financial Development: A Fillip or Impediment to Nigeria's Economic Growth. International Journal of Economics and Financial Issues, 3, 305-318.

[49] Dickey, D.A. and Fuller, W.A. (1979) Distribution of the Estimators for Autoregressive Time Series with a Unit Root. Journal of the American Statistical Association, 74, 427-431.

[50] Engle, R. and Granger, C.W.S. (1987) Co-Integration and Error Correction: Representation, Estimation and Testing. Econometrica, 55, 251-276.

[51] Phillips, P.C. and Ouliaris, S. (1990) Asymptotic Properties of Residual Based Tests for Cointegration. Econometrical: Journal of the Econometric Society, 58, 165-193. https://doi.org/10.2307/2938339

[52] Enders, W. (2008) Applied Econometric Time Series. John Wiley \& Sons, Hoboken, NJ.

[53] Wooldridge, J.M. (2013) Introductory Econometrics-A Modern Approach. Cengage Learning, Boston, MA.

[54] Kalim, R. and Shahbaz, M. (2009) Impact of Foreign Direct Investment on Stock Market Development: The Case of Pakistan. Global Conference on Business and Economics, 978.

[55] Johansen, S. and Juselius, K. (1990) Maximum Likelihood Estimation and Inference on Cointegration-With Applications to the Demand for Money. Oxford Bulletin of Economics and Statistics, 52, 169-210. https://doi.org/10.1111/j.1468-0084.1990.mp52002003.x

[56] Chandio, A.A., Jiang, Y., Joyo, M.A. and Rehman, A. (2016) Impact of Area under Cultivation, Water Availability, Credit Disbursement, and Fertilizer Off-Take on Wheat Production in Pakistan. Journal of Applied Environmental and Biological Sciences, 6, 10-18.

[57] Tijani, A.A., Oluwasola, O. and Baruwa, O.I. (2015) Public Sector Expenditure in Agriculture and Economic Growth in Nigeria: An Empirical Investigation. Agrekon, 54, 76-92. https://doi.org/10.1080/03031853.2015.1073000

[58] Izhar, A. and Tariq, M. (2009) Impact of Institutional Credit on Aggregate Agricultural Production in India during Post Reform Period. Ph.D. Thesis, Aligarh Muslim University, Aligarh, India.

[59] Dorfman, J.H. and Lastrapes, W.D. (1996) The Dynamic Responses of Crop and Livestock Prices to Money-Supply Shocks: A Bayesian Analysis Using Long-Run Identifying Restrictions. American Journal of Agricultural Economics, 78, 530-541. https://doi.org/10.2307/1243271

[60] Das, A., Senapati, M. and John, J. (2009) Impact of Agricultural Credit on Agriculture Production: An Empirical Analysis in India. Reserve Bank of India Occasional Papers, 30, 75-107.

[61] Acha, I.A. (2012). Non-Bank Financial Institutions and Economic Development in Nigeria. International Journal of Finance and Accounting, 1, 14-22.

[62] Oniyishi, L.O., Arene, C.J. and Ifiorah, C.M. (2015) An Analysis of Interest Rate Deregulation as a Policy Instrument for Stimulating Agricultural Finance and Growth in Nigeria. Nigerian Journal of Agricultural Economics, 5, 61.

[63] Sarma, M. and Pais, J. (2011) Financial Inclusion and Development. Journal of International Development, 23, 613-628. https://doi.org/10.1002/jid.1698 